Toplum Bilimleri Dergisi - Journal of SocialSciences

ISSN: 1306-7877 e-ISSN: 2147-5644

15 Kasım / November 2019, 26 : 346-364

\title{
Modern Dünyada Öznenin Ölümü ve Bir Var Olma Mücadelesi Olarak Hakikatsiz Tezahür; Teşhir
}

Death of the Subject in the Modern World and Manifestation Without Truth as a Struggle for Existence; Exhibition

\section{Ensar ÇETIN}

Doç. Dr., Nevşehir Hacı Bektaş Veli Üniversitesi, Fen-Edebiyat Fakültesi, Sosyoloji Bölümü Assoc. Prof. Dr., Nevşehir Hacı Bektaş Veli University, Faculty of Arts and Sciences,

Department of Scoiology

ensarcetin@yahoo.com

https://orcid.org/0000-0002-5668-4988

\section{Makale Bilgisi / Article Information}

http://dx.doi.org/10.29228/tbd.2007.39785

Makale Türü / ArticleTypes: Araştırma Makalesi / Research Article

Geliş Tarihi / Received: 10 Ekim / October 2019

Kabul Tarihi / Accepted: 17 Ekim / October 2019

Yayın Tarihi / Published: 15 Kasım / November 2019

Yayın Sezonu / PubDateSeason: Özel Sayı / Special Issue 2019

Cilt / Volume: 26

Sayfa / Pages: 346-364

Copyright (C) Published by Toplum Bilimleri Dergisi - Journal of Social Sciences. All rights reserved. www.toplumbilimleri.com 


\section{Modern Dünyada Öznenin Ölümü ve Bir Var Olma Mücadelesi Olarak Hakikatsiz} Tezahür; Teşhir ${ }^{1}$

Öz: Batı'da modern dönemin başlangıcında modernitenin özgürlük, refah, sanayileşme, bilimsel ilerleme, teknolojik gelişme gibi olumlu yanları vurgulanmış, modernitenin yan etkilerinin olabileceği genellikle göz ardı edilmiştir. Aydınlanma düşünürleri, doksanlı yıllarda modernitenin yan etkileri belirgin bir şekilde ortaya çıkmaya başladığında ise modernitenin yan etkileri (zararlı etkileri) olamayacağını olsa bile bu yan etkilerin modern hayatın sağladığı imkanlarla giderilebileceğini savunmuşlardır. Doksanlı yılların sonlarına gelindiğinde, modernitenin kısıtlayıcı, tek- tipleştirici, bağlayıcı ve sonuç olarak insanın yabancılaşmasına neden olan yan etkileri, görmezlikten gelinemeyecek derecede kendini hissettirmeye başlamıştır. Bu dönemde modern hayatın üretim biçimi olan kapitalizmin insanlara dayattı̆̆ı aşırı standartlaşma ve tek- tipleşme bireysel farklılıkların zamanla silinmesine, birbirinin tıpkısı olan bireylerin ortaya çıkmasına neden olmuştur. Bu ise insanın türsel özelliklerinden uzaklaşma anlamında bir tür yabancılaşmayla sonuçlanmıştır. Bu şekilde kendine yabancılaşmış, öznesi öldürülmüş birey bir varlık mücadelesine girişmiştir. Ancak kendine yabancılaşmış birey bu mücadeleyi, kapitalizmin araçlarıyla ve modern hayatın içinde kalarak verme çabasına girişmiştir. $\mathrm{Bu}$ ise bu mücadeleyi gerçek bir mücaleden ziyade bir gösteriye dönüştürmüştür. Özetle modern hayatın insanlara dayattığı "mış" gibi hayata bireyin tepkisi de "mış" gibi olmaktadır. Bu çalışmada, modern hayatın, bireyleri birbirlerine benzetmesi, insanları özne olmaktan çıkartıp adeta bir tüketim aracına dönüştürerek türsel özelliklerinden uzaklaştırması ve netice olarak insanın kendine yabancılaştırılması süreci ve bu sürecin sonunda bireyin buna karşı bir tür var olma mücadelesi olarak ortaya koyduğu "mış" gibi yaşam; hakikatsiz tezahür (teşhir) ele alınmaya çalışılmaktadır.

Anahtar Kelimeler: Sosyoloji, Modernite, Modernleşme, Sıradanlaşma, Yabancılaşma, Öznenin Ölümü, Hakikatsiz Tezahür, Teşhir.

Death of the Subject in the Modern World and Manifestation Without Truth as a Struggle for Existence; Exhibition

Abstract: At the beginning of the modern period in the West, positive aspects of modernity, such as freedom, welfare, industrialization, scientific progress and technological advancements, were underlined, while the potential side effects of the contemporary

\footnotetext{
${ }^{1}$ Bu makale, Afro Eurasian Studies Journal 7/2 (Fall 2018), 304-337, İngilizce olarak yayınlanmıştır.
} 
modernity were overlooked. When the side effects of modernity started to emerge in the nineties, the Enlightenment thinkers suggested that modernity could have no side effects and, even if it did, those side effects could be eliminated through the means provided by modern life. In the nineties, the restrictive, standardizing and binding side effects of modernity, which consequently caused the alienation of men, began to make their presence felt to an unignorable extent. The extreme standardization imposed on people by capitalism, the production method of modern life, resulted in the disappearance of individual differences by time and the appearance of highly resembling individuals, which led to a kind of alienation in the sense of growing distant from the varietal characteristics of human. Such a self-alienated individual, the subject of whom is dead, has embarked on a struggle for existence. However, the self-alienated individual struggles by using the tools of capitalism and by remaining within the modern life, which turns the struggle into a show, rather than a true struggle. In brief, the individual's reaction to the "as if" life imposed by the modern life appears as an "as if" reaction. This study focuses on the modern life's process that involves creating resembling individuals and killing the subject, and the consequential "as if" life of the individual as a struggle for existence at the end of that process; false appearance (exhibition).

Keywords: Sociology, Modernity, Modernization, Alienation, Becoming Common, Death of the Subject, Manifestation without Truth, Exhibition.

\section{KURAMSAL VE KAVRAMSAL ÇERÇEVE}

\subsection{Araştırmanın Konusu}

Araştırma konusu, egemen insan paradigması çerçevesinde biçimlenen modernitenin faydaları olduğu gibi zararlı etkileri de olmaktadır. Modernite; değişim, özgürlük, insan hakları gibi söylemlerin yanı sıra toplumları disiplin altına alma pratiklerine de dayanmaktadır. Yani modernitenin, hem özgürleştirme hem de tek tipleştirme ve disiplin altına alma yönü vardır. Bu çalışmada modernitenin insanı yabancılaştırması ve insanın bu yabancılaşmaya tepki biçimi incelenmektedir.

\subsection{Araştırmanın Amacı}

Modernitenin etkisiyle türsel özelliklerinden uzaklaşmış, yabancılaşmış, öznesi ölmüş insanın, kendini var etme mücadelesi verirken hangi kaynakları ve yöntemleri kullandığını ortaya koymak bu çalışmanın temel hedefidir. 


\subsection{Araştırmanın Önemi}

İnsan, farklı yönleriyle tanımlansa da insanı diğer varlıklardan ayıran özelliklerin başında davranışlarını bir niyetle yapması gelir. Bu özelliği insanın türsel özelliğidir. Modernite insanların hayatına çok önemli katkılar yapmıştır. Ancak modernitenin zararlı etkileri de (yan etkileri) bulunmaktadır ve bunlar her geçen gün daha çok hissedilmektedir. $\mathrm{Bu}$ yan etkilerin en önemlilerinden birisi de insanın türsel özelliklerinden uzaklaştırılmasıdır. Modern dönemde insan, kendine yabacılaşmış ve öznesi ölmüş, ne tüketeceği, ne kadar tüketeceği, ne zaman tüketeceği, nasıl tüketeceği dışarıdan belirlenen bir tüketim organizmasına dönüşmüştür. Modern insan başkalarının koyduğu hedefe ulaşmak için sürekli çalışmaktadır. Bu haliyle Kant'ın ifadesiyle; aklını kullanarak kurtulduğu ergin olmama durumundan tekrar ergin olmama durumuna düşmüş görünmektedir. İnsanın tekrar ergin olabilmesi için yine aklını bu sefer daha da çok ve etkili şekilde kullanması gerekmektedir. Bu çalışma insanların içine düştüğü ya da düşürüldüğü ergin olmama durumundan tekrar ergin olma durumuna geçebilmesine katkı sağlayacaktır.

\subsection{Araştırmanın Yöntemi}

Modernitenin etkisiyle türsel özelliklerinden uzaklaşmış, yabancılaşmış, öznesi ölmüş insan kendini var-etme mücadelesi verirken hangi kaynakları ve yöntemleri kullandığı doküman incelemesi" tekniği ve "içerik analizi" yöntemiyle incelenmiştir.

\section{Araştırmanın sorusu ve hipotezleri:}

Araştırmanın sorusu: Modern hayatın yabancılaştırma etkilerine insanın tepkisi nasıl olmaktadır?

\section{Hipotezler:}

$\mathrm{H}_{1}$ Egemen insan paradigmasıyla biçimlenmiş modern hayat insanı türsel özelliklerinden uzaklaştırmıştır.

$\mathrm{H}_{2}$ Modern insan, modernitenin zararlı etkilerine karşı mücadelesini yine modernitenin kendine sunduğu imkanlarla vermeye çalışmaktadır.

$\mathrm{H}_{3}$ Modernitenin dönüştürdüğü alanlardan biri de değerler alanıdır.

$\mathrm{H}_{4}$ Kültür endüstrisi modayı, geleneksel medyayı ve sosyal medyayı etkin ve yaygın bir şekilde kullanarak insanların gündelik hayat pratiklerini dönüştürmektedir. 


\subsection{Kavramsal Çerçeve}

\subsubsection{Modernite ve Modernleşme}

Modernite, genel olarak, 19. yüzyıl sonundan İkinci Dünya Savaşı'nın başlangıcına kadar olan dönemde, bilhassa sanat ve edebiyatta meydana gelen büyük çaplı değişimleri tanımlamak için kullanılan bir terimdir. Ancak, modernizmin açıkça sınırı belirlenmiş bir başlama ve bitiş tarihi yoktur. İkinci Dünya Savaşı'ndan beri gerçekleşen değişimleri tanımlamak için postmodern terimi kullanılıyorsa da bazı düşünürler modernizmin hâlâ sürdüğünü; bazı düşünürler ise modernizmin ölümünün söz konusu tarihten çok daha önce gerçekleştiğini iddia etmektedirler.

Modern kavramının yaygın olarak kullanılan iki anlamı vardır. Bunların ilkinde modernlik, "çağdaş" anlamında kullanılır. Bu anlamda modernite, Latince "modernus" kelimesinden türetilmiştir ve çağdaş biçimlerin, geleneksel biçimlerin yerini alması anlamına gelir. İkinci olarak ise ilerlemeyi ve gelişmeyi içeren anlamda kullanılan modernleşmedir. Bununla beraber sosyolojik olarak modernleşmenin üç tür tanımından söz edilebilir. İlk tanım analitiktir. Bu tanıma göre, modernleşme ve modern, toplumsal yapının ve toplumsal sürecin oldukça soyut niteliklerini ifade eder. Bu nitelikleri taşıdığ1 sürece bu toplumlar "modern" olarak tanımlanırlar. İkinci tanıma göre, modernleşme tarihin bir niteliğidir ve toplumsal yapıyı zenginleştiren, güçlendiren yapıların ortaya çıkması anlamında ilerlemeyi ifade eder. Bu tanıma göre, modernite ve modernleşme yeni karakterleriyle öncüllerinden ayrılmış belirli zaman dilimlerini tanımlamak için kullanılır. Üçüncü tanıma göre ise modernleşme, gelişmekte olan ülkelerin iktidar elitlerince izlenen bir seri politikaya verilen isimdir. Ülkelerinde değişimi başlatan ve sürdüren iktidar elitleri yenilikçiler olarak tanımlanır ve modernleşme bu kesimin algılarına göre içerik ve anlam kazanır. ${ }^{2}$

Modernite, geleneğe karşı bir gelenektir. Ancak iddia edildiğinin aksine gelenek ve alışkanlıkların sağladığı kesinliklerin yerini rasyonel bilginin kesinliğinin alamadığı bir düzendir. Modern dönemde, eleştirel aklın yaygın bir özelliği olan kuşku, felsefi bilinç kadar gündelik hayata da nüfuz eder ve çağdaş toplumsal dünyanın genel varoluşsal boyutunu oluşturur. ${ }^{3}$ Aynı zamanda modernitenin bu karakteristik özelliği akla mutlak güven konusundaki yaygın şüpheciliğin yanı sıra bilim ve teknolojinin çift- yüzlü olduğu, yani insanların yararına olan imkânlar sunduğu gibi yeni riskler ve tehlikeler de yarattığının kabulüdür. ${ }^{4}$

\footnotetext{
${ }^{2}$ Anthony D. Smith, Toplumsal Değişme Anlayışı (İstanbul: Gündoğan Yayınları, 2011), 95-97.

${ }^{3}$ Anthony Giddens, Modernite Birey ve Kimlik, çev. Ümit Tatlıcan (İstanbul: Say Yayınları, 2014b), 13.

${ }^{4}$ Giddens, Modernite Birey ve Kimlik, çev. Ümit Tatlıcan, 45.
} 
Modernitenin ne zaman başladığı veya özelliklerinin tam olarak neler olduğu konusunda çok az görüş birliği bulunmasına karşın, biçimsel olarak modernizm, genellikle, derinleşme, üslupçuluk, içe dönme, teknik gösteriş, içsel olarak kendinden kuşku duymaya yönelik bir hareket ve Viktorya dönemi gerçekçiliğine karşı bir tepki şeklinde tarif edilmiştir. ${ }^{5}$ Ancak modernliğe ilişkin birbirinden oldukça farklı algılayış ve kavrayışlar ortaya konmuştur. Geliştirilen onca düşünceye, ortaya konulan onca bilgiye rağmen modernitenin ne olduğu, nerede başlayıp nerede bittiği, sınırlarının nasıl belirlendiği konusunda hala ciddi belirsizlikler vardır. Bu bağlamda, modern insanla modern olmayan insanın, modern toplumla modern olmayan toplumun birbirinden nasıl ayırt edilebileceği, modernleşme, modernlik, modernite gibi kavramların hangi tanımsal içeriklere, anlamlara sahip olduğu konusunda hala önemli yorum farkları bulunmaktadır.

Modernitenin birçok boyutu olduğu kabul edilse de iki boyutunun ön plana çıktığ 1 söylenebilir. Bu boyutlardan birincisi üretim sürecinde kas gücünün yerine makine gücünün yoğun olarak kullanımı anlamında sanayileşme; ikincisi ise hem ürün piyasasının hem de iş gücünün metalaşması anlamında kapitalizmdir. Bu şekilde ortaya çıkan modern hayatın öncelikle ve özellikle Batı toplumu için önemli kazanımları olmuştur. Sosyolojinin klasik kurucuları da daha çok modernliğin bu olumlu yönlerine vurgu yapmışlardır.

Ancak ilk olarak Karl Marx, Emile Durkheim ve Max Weber modern çağın sorunlu yönlerine dikkat çekmişlerdir. Özellikle Weber, moderniteyi, maddi ilerlemenin, bireysel yaratıcılığı ve özerkliği ezen bir bürokrasinin gelişmesi pahasına elde edildiğini paradoksal olarak görmüştür. Modern toplumsal gelişim içinde uzmanlığın önemini en açık bir şekilde gören Weber'e göre, günlük deneyim, rengini ve kendiliğindenliğini yalnızca bürokrasinin "çelik sağlamlığındaki" kafesinin sınırları içinde sürdürür.6

Marx ve takipçileri ise modernliği bir canavar olarak görürler. Marx, modernliğin ne denli yıkıcı ve onarılmaz bir etkisinin olduğunu çağdaşlarından çok daha açık bir şekilde ortaya koymuştur. Marx için modernite, Habermas'ın ifadesiyle, “tamamlanmamış bir proje"dir. Ona göre, bu canavar evcilleştirilebilir; çünkü insanoğlu yarattıklarını her zaman denetimi altına alabilir. Kapitalizm, yalnızca, modern dünyayı yönetmenin akıldışı bir yoludur.

Moderniteyi “juggernaut" olarak tanımlayan ve insanlar olarak bu juggernaut'u bir dereceye kadar yönlendirebileceğimizi söyleyen Giddens, juggernaut'un denetimimizden

\footnotetext{
${ }^{5}$ Gordon Marshall, Sosyoloji Sözlüğü, çev. Osman Akınhay \& Derya Kömürcü (Ankara: Bilim ve Sanat Yayınları, 1999), 508.

${ }^{6}$ Anthony Giddens, Modernliğin Sonuçları, çev. Ersin Kuşdil (İstanbul: Ayrıntı Yayınları, 2014a), 15-16.
} 
çıkıp parça parça olabilme tehlikesine de dikkat çeker. Ona göre, juggernaut, ona direnenleri ezip geçer; bazen doğru bir yol izler gibi görünürken, bazen de önceden kestiremeyeceğimiz yönlere doğru beklenmedik bir biçimde sapıverir.7

Modernite; değişim, özgürlük, insan hakları gibi söylemlerin yanı sıra toplumları disiplin altına alma pratiklerine de dayanmaktadır. Yani modernitenin, hem özgürleştirme hem de disiplin altına alma yönü vardır. Ancak "Modernite kavramı üzerinde çalışan sosyologlar, genellikle onun disiplin altına alıcı, sınırlandırıcı ve olumsuzluklar taşıyan yönlerini öne çıkarmışlardır. Düşünce tarihinde modernliğin yıkıcı etkilerine, patolojik yönlerine, sıkıntılarına ve sınırlandırmalarına ilişkin eleştirel teşhis koyan, ona ilişkin geniş ve sistematik teoriler öneren çok sayıda sosyolog vardır." ${ }^{8} \mathrm{Bu}$ eleştirel yaklaşımlar arasında en etkili olanının ve dolayısıyla da en çok bilineninin ise "Frankfurt Okulu" olarak da bilinen "eleştirel teori" olduğu söylenebilir. Frankfurt Okulu içinde yer alan çok sayıda sosyolog modern hayatın aşırı standartlaşma, tek- tipleşme, aşırı tüketim, kitle kültürü, güven kaybı, kültürel yabancılaşma gibi yan etkilerine dikkat çekmiştir.

"Frankfurt Okulu" düşünürlerine göre, modernleşmeyle birlikte, kişisel ve yüz yüze ilişkilerin yerini ikincil ilişkiler almış, geleneksel toplum hayatının sağladığı güven ve dayanışma duygusu zayıflamaya başlamıştır. Modernite ile tek biçimcilik artmış, herkes vasat bir düzeyde eşitlenmiş, insanlar tek tip hale gelmiş, her şey standartlaşmış, akıl tutulmuş ve insanlar yeni köleliklerine hazırlanmıştır. İnsanlar bağımlı kültürün tutsağı haline gelmiştir. ${ }^{9}$ Modern dönemde birey, baskı ve denetim altına alınarak programlı biçimde bilinçsizleştirilmiştir. Bu bağlamda Frankfurt Okulu'nun, modernitenin eleştirisi konusunda öne çıkan iki mensubu Marcuse ve Adorno, modern sanayi toplumlarının, üyelerinin iç dünyası üzerinde büyük bir denetim uygulandığını ancak bireylerin kendi mutsuzluklarının ve sefilliklerinin dahi farkına varamadıklarını belirtmektedirler. ${ }^{10}$ Modernleştirme sürecinde toplumlar, o denli tek tipleştirilmiştir ki, kendi kültürlerini kaybetme noktasına gelmiştir. Modernleşme düşünürleri ve eleştirmenleri tartışmalarının önemli bir kesitine kültürü koyarlar. Özellikle de Frankfurt Okulu düşünürlerinin yaptıkları kültür analizlerinde kitle kültürü olgusu merkezdedir. Onlara göre, modernleşme süreci, geleneksel kültür değerlerini yok ederken onların yerine yapay bir kültürel üretim türü olan kültür endüstrisini koymuştur. ${ }^{11}$

\footnotetext{
${ }^{7}$ Giddens, Modernliğin Sonuçlarl, çev. Ersin Kuşdil, 137.

${ }^{8}$ Sezgin Kızılçelik, Sosyal Bilimleri Yeniden Yapılandırmak (Ankara: Anı Yayıncılık, 2004), 10.

${ }^{9}$ İrfan Erdoğan \& Korkmaz Alemdar, Öteki Kuram (Ankara: Erk Yayınevi, 2002), 410.

${ }^{10}$ Kızılçelik, Sosyal Bilimleri Yeniden Yapılandırmak, 16.

${ }^{11}$ Süleyman Güngör, Türkiye Cumhuriyeti’nin İlk Yıllarında Politikacı-Aydın İlişkisi (Ankara: Nobel Yayınları, 2001), 230.
} 


\subsubsection{Kültür Endüstrisi}

Frankfurt Okulu'nun iki önemli temsilcisi Adorno ve Horkheimer, ilk defa "The Culture Industry: Enlightenment as Mass Deception" isimli çalışmasında, kültürün rasyonel kapitalizm tarafından nesneleştirilmesini açıklamak için "kültür endüstrisi" kavramını kullanmışlardır. Onlara göre; kültür endüstrisi ile kitle kültürü, beyin yıkama ve toplumsal denetim aracı olarak yukarıdan dayatılan ve yönetilen bir kültürdür. İdeolojik bir tahakküm biçimi olan kültür endüstrisinde insanileştirme ve özgürleştirme yoktur. ${ }^{12}$ Tüketici, kültür endüstrisinin savunduğu gibi özne değildir, aksine kültür endüstrisinin nesnesidir. ${ }^{13}$

Kültür endüstrisi ürünleri, sonradan metalaşan ürünler değil, aksine daha en başından piyasa için üretilmiş metalardır. Kültür endüstrisini harekete geçiren temel dinamik piyasadır. Bu nedenle, kültüre damgasını vuran temel güdü en geniş satışı yakalamak ve kısa sürede maksimum kâra ulaşmak olmuştur. Gelişmiş kapitalizmdeki kültürel üretimin yapılanması her şeye damgasını vuran bir tekdüzelik sorunu yaratmıştır. Adorno ve Horkheimer'ın kendi sözleriyle; “Bugün kültür endüstrisi her şeyi birbirine benzetmektedir. Filmler, radyo ve dergiler bir sistem oluşturuyor. Her alan kendi içinde ve diğerleriyle bir sistem oluşturmaktadır." Kısaca, artık tüm dünya kültür endüstrisinin süzgecinden geçmek zorunda bırakılmıştır. ${ }^{14}$ Adorno ve Horkheimer'ın kitle kültürüne yönelik oldukça kötümser ve olumsuz bu yaklaşımının, yani kitle toplumu kavramsallaştırmasının geri planında artan endüstrileşme ve kentleşmeyle birlikte gelişen kitle iletişim araçlarının geleneksel bağları çözmesinin sonucu yalıtılmış, yabancılaşmış ve pasifleşmiş insanlardan oluşan bir toplumun önemli payı vardır. ${ }^{15}$

Günümüzde kültür endüstrisi her şeye benzerlik katmıştır. Televizyon, sinema, radyo, dergi ve gazeteler bir sistem meydana getirmektedirler. Her bir alan kendi içinde ve hep birlikte söz birliği içindedirler. Sinema, radyo, televizyon günümüzde kendisini sanat olarak göstermek zorunda değildir. Bunlar herhangi bir işten farklı bir iş olmadıkları gerçeğini, ürettiklerini meşrulaştıran bir ideoloji olarak kullanırlar. ${ }^{16}$ Hangi olay örgüsü seçilirse seçilsin tüm filmler, sermayenin mutlak kudretini iş arayan mülksüzleştirilmiş yığınların yüreğine efendilerinin iktidar gücü olarak kazımak içindir. ${ }^{17}$ Kültür endüstrisi taklit olanı mutlak hakikatin yerine koyar. Kapitalist sistem insanların bedenlerini ve

\footnotetext{
${ }^{12}$ Douglas Kellner, Kültür Endüstrileri, Kitle iletişim Kuramları (Ankara: Ütopya Yayınevi, 2005), $102-105$.

${ }^{13}$ Theodor. W. Adorno, Kültür Endüstrisini Yeniden Düşünmek, Cogito 36 (Yaz 2003), 76.

${ }^{14}$ W. Thedor Adorno \& Max Horkheimer, Aydınlanmanın Diyalektiği, çev. Nihat Ülner \& Elif Öztarhan Karadoğan (İstanbul: Kabalcı Yayınları, 2014), 7.

15 Alan Swingwood, Kitle Kültürü Efsanesi (Ankara: Bilim ve Sanat Yayınları, 1996), 33.

${ }^{16}$ Adorno \& Horkheimer, Aydınlanmanın Diyalektiği, çev. Nihat Ülner \& Elif Öztarhan Karadoğan, 162-163.

${ }^{17}$ Adorno \& Horkheimer, Aydınlanmanın Diyalektiği, çev. Nihat Ülner \& Elif Öztarhan Karadoğan, 167.
} 
ruhlarını öylesine kuşatmıştır ki önlerine konulan her şeye direniş göstermeden kapılmaktadırlar. Hükmedilenlerin, hükmedenlerden gelen ahlakı onlardan fazla ciddiye alması gibi, günümüzün aldatılan kitleleri de başarı mitosuna gerçekten başarılı olmuş kişilerden çok daha fazla kapılmaktadır. ${ }^{18}$ Kültür endüstrisi, sürekli vaat ettiği şeylerle tüketicisini aldatır. Olay örgüleri ve ambalajlamayla verilen haz senedinin vadesi asla gelmez. Zaten sadece vaatten ibaret olan bütün bu gösteri haince bir biçimde hiçbir zaman gerçekleşmez. ${ }^{19}$

Kültür endüstrisinde belirleyici olan ilke; sistemin içindeki tüketicilerin iplerini elden bırakmamak ve tüketiciye bir an olsun direnişin mümkün olduğu izlenimini vermemektir. $\mathrm{Bu}$ ilke, bir yandan tüm tüketici gereksinimlerinin kültür endüstrisi tarafından giderilmesini dayatırken diğer yandan bu gereksinimleri önceden insanın hep bir tüketici, sadece kültür endüstrisinin bir nesnesi olarak yaşamasını sağlayacak biçimde düzenlenmektedir. Kültür endüstrisi bu aldatmacayı tüketiciye doyum diye sunmakla kalmaz, bunun da ötesinde tüketicinin zihnine, ona ne sunuluyorsa onunla yetinmesi gerektiğini işler. ${ }^{20}$ Modern hayat için, şaşkın sürü bir sorundur. Bu nedenle onların sesini yükseltmesi ve düzene karşı gelmesi engellenmelidir. Onlar başka şeylerle oyalanmalıdır. Onlar, süper lig maçlarını, televizyon dizilerini ya da şiddet filmlerini izlemelidir. Eğer olan biteni fark ederlerse, süper lig maçları ve televizyon dizilerini seyretmelerini sağlamak yeterli olmayabilir. $O$ zaman düşman korkusunun körüklenmesi gerekir. ${ }^{21}$

Kültür endüstrisinde herkes bir başkasının yerine geçebilecekleriyle vardır. Herkes yedektir ya da yalnızca türünün sıradan bir örneğidir. Birey olarak herkesin yeri kesinlikle doldurulabilirdir. İnsan salt bir hiçliktir ve bunu zamanla o benzerliği kaybettiğinde iyice hissetmeye başlar. Böyle insanların sıkı sıkıya bağlı oldukları "başarı dini”nin içeriği değişmiş olur. İnsanlar, bir taraftan olduklarından başka kimseler olmak zorunda olmadıklarına ve yapamayacaklarını bildikleri şeyleri yapmadan da başarılı olabileceğine inandırılırken, diğer taraftan insanlara, çabalarının herhangi bir yararı olmayacağı ima edilir. Çünkü burjuva şansı ile harcanan emeğin hesaplanabilir etkisi arasında herhangi bir bağlantı kalmamıştır. ${ }^{22}$

Mesleki gelişimde, özellikle serbest mesleklerde uzmanlık bilgilerinin ilke olarak kuralcı bir zihniyete bağlı olması, başarı için yalnızca uzmanlık bilgilerinin yeterli olduğu

\footnotetext{
${ }^{18}$ Adorno \& Horkheimer, Aydınlanmanın Diyalektiği, çev. Nihat Ülner \& Elif Öztarhan Karadoğan, 179.

${ }^{19}$ Adorno \& Horkheimer, Aydınlanmanın Diyalektiği, çev. Nihat Ülner \& Elif Öztarhan Karadoğan, 186.

${ }^{20}$ Adorno \& Horkheimer, Aydınlanmanın Diyalektiği, çev. Nihat Ülner \& Elif Öztarhan Karadoğan, 189.

${ }^{21}$ Noam Chomsky, Medya Denetimi (İstanbul: Everest Yayınları, 2013), $11-12$.

${ }^{22}$ Adorno \& Horkheimer, Aydınlanmanın Diyalektiği, çev. Nihat Ülner \& Elif Öztarhan Karadoğan, 19.
} 
yanılsamasını doğurmaktadır. Oysa işin aslı, bu toplumun irrasyonel planlamacılığının bir parçası olarak yalnızca sisteme sadık olanların yaşamları bir ölçüde yeniden üretilir. Yaşam standardının basamakları tam olarak farklı tabakaların ve bireylerin sisteme duydukları içsel bağlılık düzeyine karşılık gelir. Bu, topluma ahlaki uygunluklarını her seferinde yeniden göstermeleri için herkese zorla benimsetilen tavır, kabileye giriş sırasında rahipten tokat yerken gülücükler saçarak daireler çizen oğlan çocuklarını hatırlatır. Kültür endüstrisinde var olmak hiç bitmeyen erginlenme ayinidir. Herkes, tokatları indiren erkle tepeden tırnağa özdeşleştiğini göstermek zorundadır. Herkes her şeye gücü yeten toplum gibi olabilir, herkes mutluluğa kavuşabilir, yeter ki etiyle kemiğiyle teslim olsun ve mutluluk talebinden vazgeçsin. Toplum bireyin zayıflığında kendi kuvvetini fark eder ve bir kısmını ona geri verir. Gelgelelim toplumun dayandığı birey toplumun kusurunu kendi içinde barındırmaktadır. Çünkü birey görünüşte özgür olmasına rağmen gerçekte toplumun ekonomik ve sosyal aygıtlarının bir ürünüdür. ${ }^{23}$

Kültür endüstrisi hiç de öyle olmadığı halde, dünyanın en iyi orkestraları olarak nitelendirilen orkestraları ücretsiz olarak evlere kadar getirir. Senfoni, başlı başına radyo dinlemenin veya televizyon seyretmenin ödülü haline gelir. Alay edercesine dünya, eğlenceden ibaret bir cennet olarak sunulur. Her film bir sonraki filmin fragmanıdır. " $x$ " dergisine abone olmak nasıl zorunluluksa " $y$ " televizyon kanalında gösterilen $\mathrm{Z}$ dizisini seyretmek de bir zorunluluktur. Her şey, kendisi bir şey olduğu için değil, alınıp satıldığı sürece değerlidir. ${ }^{24}$

Reklam, kültür endüstrisinin yaşam iksiridir. Kültür endüstrisi bir meta olarak vaat ettiği keyfi durmaksızın salt bir vaade indirgediği için, sonunda keyif verememekten ötürü reklama gereksinim duyar. Reklamın arkasında sistemin egemenliği gizlenmektedir ve tüketicileri büyük endüstriyel birliklere zincirleyen bağları daha da güçlendirmektedir. Reklamı yapılmayan, reklamın damgasını taşımayan her ürün iktisadi açıdan şaibeli olarak görülmektedir. ${ }^{25}$ Reklam metni mal satmak veya hizmeti tanıtmak işlevinin yanı sıra insana düş gördürür. Reklam görüntüsü illüzyon yaratır. Sürekli yeni, bilmediğimiz, gizemli hayatları işaret eder. Kendi sözlüğümüzde bulunmadığı için tam olarak ne anlama geldiğini bilmediğimiz türden tatminlere ulaşma vaadiyle yeni arzu nesneleri üretir. ${ }^{26}$

\footnotetext{
${ }^{23}$ Adorno \& Horkheimer, Aydınlanmanın Diyalektiği, çev. Nihat Ülner \& Elif Öztarhan Karadoğan, 200.

${ }^{24}$ Adorno \& Horkheimer, Aydınlanmanın Diyalektiği, çev. Nihat Ülner \& Elif Öztarhan Karadoğan, 208.

${ }^{25}$ Adorno \& Horkheimer, Aydınlanmanın Diyalektiği, çev. Nihat Ülner \& Elif Öztarhan Karadoğan, 215 - 216.

${ }^{26}$ Didem Dayı, "Metafor, Bellek, Görüntü”, Görüntü Üretimi ve Gündelik Hayat (İstanbul: Kırk Yayınevi, 2013), 28.
} 
Kültür endüstrisi, zihinsel sapmalar konusunda pek duyarlı sayılmayan girişimci demokrasinin uygarlaştırıcı mirasını devralmış durumdadır. Herkes dans edip eğlenmekte özgürdür. Ancak sürekli iktisadi zorlamayı yansıtan ideolojinin seçimine ilişkin bu özgürlüğün, bütün alanlarda hep aynı olanı seçme özgürlüğü olduğu görülür. İnsanların en mahrem tepkileri öylesine "şey"leşmiştir ki kendine özgü olma fikri varlığını ancak uç noktalardaki bir soyutlulukta sürdürür. Kişilik parlak beyaz dişlere sahip olmaktan ve koltuk altı terinden kurtulmaktan öte bir anlam taşımaz hale gelmiştir. Reklamın kültür endüstrisindeki zaferi budur; tüketicinin, ne olduklarını gördüğü halde, kültür metalarını mecburi taklit etmesidir. ${ }^{27}$ Reklamlarda tanıtılan ürüne usulca sokulan, sımsıkı sarılan, onu içine sokacakmış gibi seven, hatta ona tapınıyor gibi yapan reklam modelleri boy gösterir. Bu tür reklam modellerinin boy gösterdiği binlerce reklamda mutluluk tabloları vardır. Ancak burada önemli olan onların mutlu olmaları değildir. Önemli olan onların mutluluk kaynağını ele geçirmektir. Yani bu koşullu mutluluktur. ${ }^{28}$ Toplumsal olayların en ciddi olanının bile "düşünülmesi gerekenden" çıkartılarak "eğlencelik olan” kalıplara sokulması günümüz medyasının ana stratejisidir. ${ }^{29}$

\section{KÜLTÜR ENDÜSTRİSİ VE DEĞER ALANI}

Kültür endüstrisinden dini semboller, ibadetler ve değerler de nasibini fazlasıyla almaktadır. Örneğin Apple firması İslam dininin temel simgelerini taşıyan cihazın alt kısmına üç boyutlu olarak Arapça kaligrafi halinde "Kelime-i Şehadet" ve yine cihazın üst kısmına ise hilal ve yıldız içerisine "Mescid-i Nebevı̂” görüntüsü olan Müslümanlara özel cep telefonu modelini piyasaya sürmüştür. Müslümanlar için özel olarak üretilmiş bu beyaz ve sarı altın kaplamalı telefonlar, aynı firmanın aynı model telefonlarının dört- beş katı fiyatlarla satılmaktadır. Diğer bir örnekte ise "kapanmak", “örtünmek" veya "gizlenmek" anlamına gelen ve dini bir anlamı olan tesettür bir teşhire dönüşmektedir. Kültür endüstrisinin en etkili oyuncularından birisi kabul edilen, kapitalizmin önemli sembollerinde biri olan ve adını Yunan mitolojisindeki zafer tanrıçası Nike'tan alan Nike firması Müslüman kadın sporcular için başörtüsü üretmektedir. Tesettür moda dergileri yayınlanmakta, ülkenin en tanınmış mankenleriyle tesettür defileleri düzenlenmektedir. Televizyonlar, dergiler, gazeteler, toplu taşıma araçları üzerinde ve billboardlarda (ilan panosu) her gün yer alan tesettür reklamları teşhirde sınır tanımamaktadır. Böylece tesettür, kültür endüstrisinin en önemli araçlarından olan moda, defile, reklam ve markalaşma ile

\footnotetext{
${ }^{27}$ Adorno \& Horkheimer, Aydınlanmanın Diyalektiği, çev. Nihat Ülner \& Elif Öztarhan Karadoğan, 221 - 222.

${ }^{28}$ Kurtcebe Turgul, "Görüntü Üretimi ve Gündelik Hayat Üzerine Yüzeysel Notlar”. Görüntü Üretimi ve Gündelik Hayat (İstanbul: Kırk Yayınevi, 2013), 65-66.

${ }^{29}$ Neil Postman, Televizyon Öldüren Eğlence, çev. Osman Akınhay (İstanbul: Ayrıntı Yayınları, 2010 ), 12.
} 
metalaşmakta esas anlamından ve işlevinden uzaklaşmaktadır. Tesettürde moda ve markalaşmayla birlikte tesettür bir teşhire dönüşebilmektedir. Türkiye'de de bunun çok sayıda örneğini görmek mümkündür.

Türkiye'de ilk tesettür defilesi 1992 yılında kendine İslam dininin önemli kavramlarından birini isim olarak seçmiş olan bir firma tarafından yapılmıştır. Sunmak teşhir etmek, sergilemek anlamlarına gelen "defile" kelimesiyle; örtünmek, kapanmak, gizlenmek anlamlarına gelen "tesettür" kelimesi bir araya getirilmiş, tesettürün defilesi yapılmış ve tesettür defilesi denmiştir. Tesettür defilesi ilk zamanlarda, tesettürün defilesi olur mu şeklinde biraz tartışılmış olsa da gelinen noktada bu durum artık kanıksanmış gözükmektedir. 2011 yılında yayınlanmaya başlanan ve tesettür modasının kurumsallaşmasında büyük etkisi olmuş bir dergi ise yayınlandıktan sonra üçüncü ayında kırk bin baskı yapmıştır.

\section{GÖSTERI DÜNYASI}

Gösterge, kendisi o şey olmadığı halde, o şeyin yerine geçerek o şeymiş gibi bize bilgi ileten bir aracıdır. Örneğin, otomobilin benzin deposundaki benzini gösteren benzin göstergesi, 1sı̈̈lçer, trafik işaretleri, bir resim, fotoğraf, sözcük, ses kaydı hepsi birer göstergedir. ${ }^{30}$ İnsanlar her dönemde bizzat tecrübe etmenin zorluklarını veya engellerini aşmak için başta görüntü ve ses olmak üzere çeşitli araçlar, aracılar kullanmışlardır. Bunların içinde saklanması ve taşınması daha kolay olduğu için resim, fotoğraf, görüntü ve ses kaydı daha yaygın kullanılmaktadır. Uzun yıllar bu aracıların ilettiği bilgilerin gerçeği en iyi şekilde yansıttığı kabul edilmiştir. Örneğin bir olayın gerçekten olup olmadığının kanıtı olarak görsel ve işitsel araçlar gerçeklik delili olarak görülmüş, bir şeyin gazetede yazılması, televizyonda gösterilmesi onun gerçekliğine delalet etmiştir.

Ancak günümüz dünyasında, gerçeğin yerine geçerek o gerçek hakkında bize bilgi iletmenin aracı olarak kullanılan ses ve görüntünün manipülasyonu mümkün hale gelmiştir. Günümüzde sesler ve görüntüler gerçeği yansıtmaktan çok belli bir amaca yönelik olarak üretilebilmektedir. Gerçeği yansıtan ses ve görüntü ile gerçeklik inşa eden ses ve görüntü arasındaki fark da neredeyse ortadan kalkmıştır. Günümüzde multimedya olanakları kullanılarak, bir kimse veya olay olduğundan tamamen farklı gösterilebilmektedir. Hatta hiç olmamış bir olayı olmuş gibi var olmamış birisini varmış gibi gösteren görüntüler üretilebilmektedir. Bu, gerçeğin yansıması olarak kabul edilen ses ve görüntünün manipülasyonu anlamına gelmektedir.

\footnotetext{
${ }^{30}$ Fatma Erkman, Göstergebilimine Girişs (İstanbul: Alan Yayıncılık, 1987), 9-10.
} 
Bugün gelinen noktada, doğal olanın bilinç tarafından algılanışının, yapay olanın algısından farklı olmadığı kabulü ile hareket edilmektedir. ${ }^{31}$ Modern toplumların tüm yaşamı gösterilerin uçsuz bucaksız birikimi olarak görünür. Geleneksel dünyada dolaysız yaşanan her şey, modern dünyada yerini bir temsile bırakmıştır. Yaşamın her bir veçhesinden kopmuş olan imajlar, bu yaşamın birliğini yeniden kurmanın artık mümkün olmadığı ortak bir akışta kaynaşır. Kısmi olarak göz önüne alınan gerçeklik, ayrı bir sahtedünya olarak, salt seyrin nesnesi olarak, kendi genel birliğinde sergilenir. Dünyasal imajlardaki uzmanlaşma, insanın kendi kendine yalan söylediği özerkleşmiş imaj aleminde kendini tamamlanmış bulur. Genel anlamda gösteri, yaşamın somut tersyüz edilişi olarak, canlı olmayanın özerk devinimidir. ${ }^{32}$

Kendi bütünlüğü içinde ele aldığımız gösteri, modernitenin hem sonucu hem de tasarımıdır. Gösteri, gerçek dünyaya bir eklenti, ona ilave edilen bir süs değildir. $\mathrm{O}$, gerçek toplumun gerçek-dışılığının can alıcı noktasıdır. Gerek enformasyon gerek reklam ya da eğlence tüketimi şeklinde olsun bütün özel biçimleriyle gösteri, toplumsal olarak hâkim olan yaşamın mevcut modelini oluşturmaktadır. ${ }^{33}$

Günümüzde gösteri kültürü önemli derecede gelişme kaydetmiştir. Gösteri, kendine has mantığı sayesinde kültürün her çeşidinde ve toplumsal hayatın birçok alanında yaygınlaşmıştır. Filmler, yüksek teknolojinin getirdiği özel efektleriyle hiç olmadı̆̆ı kadar artmış ve göz kamaştırıcı bir hal alarak, sinematografik gösterinin alanını genişletmiştir. Medya kültürü, neyin gerçek, neyin önemli ve hayati olduğuna karar vererek, toplumsal ve politik konularda hükmetmeyi sürdürmektedir. ${ }^{34}$

Aslen bir tüketici olan günümüz moda dünyasında, lazer gösterileriyle, zirvedeki rock ve pop müzik yorumcularının katılımıyla, ünlü mankenlerle ve sonu gelmeyen abartılı reklamlarla, son derece özenle hazırlanmış, yeni sezonlar için muhteşem defileler düzenlenerek her birinin tanıtımı yapılmaktadır. İnsanlara nasıl görünmeleri gerektiği bu şekilde bildirilmektedir. ${ }^{35}$

Gösteri kendini tartışılmaz ve erişilmez devasa bir olumluluk olarak sunar. “Görünen şey iyidir, iyi olan şey görünür" der, başka bir şey demez. Gerçek dünyanın basit imajlara dönüştüğü yerde, basit imajlar gerçek varlıklar ve hipnotik bir davranışın etkili motivasyonu

\footnotetext{
${ }^{31}$ Elvan Tekcan, “Tükenen Tüketim Çağında Hakiki Gerçekliğine Öykünen San'at”, Görüntü Üretimi ve Gündelik Hayat (İstanbul: Kırk Yayınevi, 2013), 33

32 Guy Debord, Gösteri Toplumu (İstanbul: Ayrıntı Yayınları, 2017), 34.

${ }^{33}$ Debord, Gösteri Toplumu, 35.

${ }^{34}$ Douglas Kellner, Medya Gösterisi (İstanbul: Aç1lım Kitap, 2013), 8-10.

${ }^{35}$ Kellner, Medya Gösterisi, 8-10.
} 
haline gelir. Spekülatif evrende değerini yitirmiş olan şey, herkesin somut yaşamıdır. Gösteri uyuma arzusundan başka bir şey ifade etmeyen zincire vurulmuş modern toplumun gördüğü düştür. Gösteri, bu uykunun bekçisidir. Gösteri kendi kendinin ürünüdür ve kurallarını kendisi koyar. O bir sahte- kutsaldır. ${ }^{36}$

Aldatıc1, yanıltıcı, sahtekâr, baştan çıkarıcı, kurnaz, dalavereci; bu kelimelerin tamamı birleştirildiğinde bugün gösteri toplumunun portresini yaparken kullanılabilecek bir renk paleti meydana gelir. ${ }^{37}$ Gösteri, üç gün boyunca bir şeyden bahsetmediği zaman o şey hiç var olmamış gibidir. Çünkü gösteri başka bir şey söylüyordur ve kısaca bundan böyle var olan o başka şeydir. ${ }^{38}$ Tahakküm kendisini genellikle sahte saldırılarla korur ve bu saldırıların medyada ele alınış tarzı asıl harekâtı örtbas edecektir. ${ }^{39} 11$ Eylül olayı bunun ilk akla gelen örneğidir. İnsanların büyük bir kısmı 11 Eylül olayının gerçek bir saldırı olmadığı, ABD'nin Irak'ın işgaline gerekçe oluşturmak için bu sahte saldırıyı düzenlediğine inanmaktadır.Diğer bir örnek ise yine Irak'ın işgali öncesinde Amerikan ABC kanalında, Amerikan meclis toplantısında insanlık dışı şiddetten bahseden ve Kuveytli bir mültecinin tanıklığına dayanılarak yayınlanan haberde Kuveytli tanık; ağlayarak Irak birliklerinin Kuveyt hastanelerindeki bebekleri kuvözlerinden çıkartıp ölmeleri için beton zemine bıraktığını ve yerinden söktükleri kuvözleri Irak'a götürdüklerini söylemiştir. Fakat daha sonra bu ağlayarak Irak askerlerinin bebeklere yaptıklarını gördüğünü söyleyen tanık kız çocuğun, ABD'deki Kuveyt Büyükelçisinin kızı olduğu ortaya çıkmıştır.

Konuyla ilgili başka bir örnek; ABD'de Woodrow Wilson, Birinci Dünya Savaşı'nın tam ortasında "Zafersiz barış" sloganıyla başkan seçilmiştir. Son derece pasif olan Amerikan halkı bir dünya savaşına girmek için herhangi bir neden görmüyordur. Ancak savaş için çoktan imza atmış olan Wilson hükümetinin halkı savaşa ikna etmesi gerekmektedir. Hükümetin bu amaçla kurduğu propaganda komisyonu altı ay içinde etkisini göstermiş barışçıl Amerikan halkını histerik bir savaş çı̆̆ırtkanına dönüştürmüştür. Altı ay gibi kısa bir süre önce savaş istemeyen Amerikan halkı, Alman olan her şeyi yakıp yıkmak, tüm Almanları lime lime etmek, savaşa girip dünyayı kurtarmak isteyen insanlara dönüşmüştür. ${ }^{40}$ Mantık olarak totaliter toplumlarda cop hangi işlevi görüyorsa demokrasilerde de medya aynı işlevi görmektedir. Bu bilgece ve iyidir; çünkü şaşkın sürüye dönüşmüş halk kendisi için iyi olanın ne olduğunu bilemez. ${ }^{41}$

\footnotetext{
${ }^{36}$ Debord, Gösteri Toplumu, 37-41.

${ }^{37}$ Debord, Gösteri Toplumu, 195.

${ }^{38}$ Debord, Gösteri Toplumu, 177.

${ }^{39}$ Debord, Gösteri Toplumu, 204.

${ }^{40}$ Chomsky, Medya Denetimi, 1.

${ }^{41}$ Chomsky, Medya Denetimi, 7.
} 
Medyadan bize sunulan mesajlar yaşadığımız hayatın ve meydana gelen olayın kendisi değildir. Kurmaca bir öyküyle karşı karşıya kalırız. Böylece egemen ideoloji içerisine yerleştirilen kodlar, anlam verdikleri her olayı inşa ederek, egemen ideolojinin uygun gördüğü biçimde, sunuş tarzında nesnellik ve yansızlık maskelerini de kuşanarak "şeyleri" kendi istedikleri anlamlara dönüştürür. ${ }^{42}$ Medyanın her türlü anlam iletiminde ister politik ister eğitici isterse de kültürel anlam taşısın esas amacı kendi çıkarına uygun biçimde anlam yitimi oluşturarak bireyleri egemenliği altına sokmaktır. ${ }^{43}$

Bir haberi televizyon veriyorsa o haber önemlidir ve doğrudur düşüncesi yaygındır. İşin aslı ise bu değildir. Televizyonun birinci ve en önemli görevi haber yayını boyunca seyirciyi etkilemektir. Bunu da haberleri etkileyici bir dile dönüştürerek yapmaktadır. Televizyon güzel bir görüntü gösterdiğinde ve görüntüyü küstah bir yalanla yorumladığında, seçkin olmayanlar her şeyin açık seçik olduğuna inanır. Yarı seçkin kişi, neredeyse her şeyin karanlıkta kaldığını, iki yönlü olduğunu ve bilinmeyen kodlar tarafından "oluşturulduğunu" bilmekle yetinir. Daha müstesna bir elit ise ulaşabildiği bütün gizli bilgilere ve sırlara rağmen her özel durumda açıkça ayırt edilmesi güç olan doğruyu öğrenmek isteyecektir. $\mathrm{O}$, bu aşkı genellikle karşılıksız kalmasına rağmen hakikatin yöntemini öğrenmekten keyif duyacaktır. ${ }^{44}$

\section{YABANCILAŞMA (ÖZNENIN ÖLÜMÜ)}

Modern kavramı yaygın olarak "çağdaş" anlamında kullanılır. Modernite, ismini, Latince'de anı, şimdiyi önemseme ve yüceltme anlamına gelen "modernus" kelimesinden almıştır ve çağdaş biçimlerin geleneksel biçimlerin yerini alması anlamında kullanılmaktadır. Modernitenin, kendi dinamikleriyle kendi modernleşmesini gerçekleştirmiş olan Batı'ya özgürlük, eşitlik, hukukun üstünlüğü, demokrasi, insan hakları, sağlık, eğitim, sanayileşme, iletişim, ulaşım imkanlarının artması yaşam koşullarının iyileşmesi gibi çok sayıda olumlu etkisi olmuştur. Ancak modernitenin karakteristik özelliği, akla mutlak güvenin yanında bilim ve teknolojinin çift-yüzlülügüüdür. Yani bilim ve teknolojinin insanlığın yararına imkanlar sunduğu kadar insanlar için risk ve tehlikeler barındırdığının kabulüdür. ${ }^{45}$

Modernitenin Batı toplum hayatına çok sayıdaki olumlu etkilerinin yanında çok sayında olumsuz etkileri de olmuştur. Pozitivizm, bilimcilik ve rasyonel kapitalizmin

\footnotetext{
${ }^{42}$ Soner Yağlı, "Gündelik Hayatımızda Akıl Tutulması: Medya Uygulamalarında Tüketim İdeolojisinin İzlerini sürmek”, Gündelik Hayat ve Medya (Ankara: Babil Yayınları, 2006), 13.

${ }^{43}$ Jean Baudrillard, Sessiz Yı̆̆ınların Gölgesinde ya da Toplumsalın Sonu (İstanbul: Ayrıntı Yayınları, 1991$), 24$.

${ }^{44}$ Debord, Gösteri Toplumu, 208.

${ }^{45}$ Giddens, Modernite Birey ve Kimlik, 45.
} 
etkisiyle tanzim edilen modern hayatın aşırı standartlaşma, tek- tipleşme, aşırı tüketim, kitle kültürü, güven kaybı, kültürel yabancılaşma gibi çok sayıda yan etkileri özellikle doksanlı yılların sonlarında ortaya çıkmıştır. Modernitenin bu yan etkileri modern dönemin ilk başlarında önemsenmemiş, görmezlikten gelinmiş veya modernitenin neden olduğu sorunların yine modernitenin imkanlarıyla çözüleceği iddia edilmiştir. Moderniteyi kendi iç dinamikleriyle gerçekleştirememiş bu nedenle Batı'yı örnek alarak veya taklit ederek moderleşmeye çalışan toplumlar ise modernitenin nimetlerinden daha çok yan etkilerine maruz kalmışlardır. Bu ise Batı dışındaki toplumların modernitenin yan etkileriyle mücadelesini daha da zorlaştırmıştır.

Kapitalist sistem, gazete, dergi, radyo, televizyon, sinema vb. araçlar; moda ve reklam vb. yöntemlerle insanları sıradanlaştırmış, yabancılaştırmış ve sonuç olarak insanları öznesi ölmüş, adeta bir "tüketim mankurtları"na dönüştürmüştür. Ancak kapitalist sistem kendine yabancılaştırdığı insanın tamamen ölmesi veya kapitalizm dışında başka arayışlara girmesini önlemek için çeşitli araçlar ve yöntemler geliştirmektedir. Bu amaçla geliştirilen yeni araç internet ve sosyal medya ve yöntem ise hakikatsiz tezahür teşhirdir. Internetin ve devamında sosyal medyanın icadıyla öznesi ölmüş modern insana, yapay bir özne oluşturma ve bunu sınırsız bir şekilde yayma, teşhir etme imkânı verilmiştir.

\section{BİR VAR OLMA MÜCADELESİ OLARAK TEŞHİR (HAKİKATSİZ TEZAHÜR)}

Teşhir kavramı, genel olarak, gündelik hayatta var olan bir şeyi göstermek, sergilemek, herkese duyurmak; bir olayı dile düşürmek, bir hükümlüyü ceza olarak halka göstermek, ticari bir ürünü tanıtmak için göstermek gibi anlamlarda kullanılmaktadır. Kavramın bu şekillerde kullamınlarına bakıldığında genel olarak, gündelik hayatta var olan, ancak gizli olan bir gerçeğin açığa vurulması anlamında kullanıldığı görülmektedir. Ancak modern dünyada başta medya, sosyal medya, estetik cerrahi ve kozmetik olmak üzere bir çok alanda meydana gelen gelişmeler temel teşhir araçları olan ses ve görüntünün manipülasyonu mümkün hale gelmiştir. Böylece hakikatin teşhiri olan ses ve görüntünün manipüle edilebilmesi teşhir araçları ile hakikat arasındaki bağı zayıflatmış, hatta koparmıştır. $\mathrm{Bu}$ ise olan bir şeyin olduğundan farklı gösterilmesi, sunulması veya hiç olmayan bir şeyin varmış gibi gösterilmesi, sunulması anlamında "hakikatsiz tezahür"dür.

Modern hayatın dayatmaları sonucunda kendine yabancılaşmış modern dönem insanı düştüğü bu kendine yabancı olma durumundan kurtulmak için uğraşmakdadır. Ancak modern dönem insanı, modern hayatın dayatmalarıyla düştüğü yabancılaşma durumundan yine modern hayatın içinde kalarak ve modern hayatın sağladı̆̆ı araç gereçlerini kullanarak kurtulmaya çalışmaktadır. Bu nedenle modern dönem insanı bunu 
yaparken içine düştüğü çelişkili durumu bizzat kendisi sürdürür. Bir taraftan kozmetik ürünlerini kullanarak ve estetik ameliyatlar olarak modern hayatın bir dayatması olan kültür endüstrisinin ideal insan tipine benzemeye, yani kendini sıradanlaştırmaya çalışırken diğer taraftan gelişen multi- medya imkanlarını kullanarak oluşturduğu içerikleri sosyal medyada teşhir ederek ben farklıyım ve buradayım mesajını vermeye çalışmaktadır.

Facebook, 2017 Haziran ayında kullanıcı sayısının 2 milyara ulaştığını duyurmuştur. $\mathrm{Bu}$ sayı diğer sosyal medya hesaplarını hesaba katmasak bile dünyada neredeyse her üç kişiden birinin sosyal medyayı kullandığı anlamına gelmektedir. Türkiye'de ise “Digital in 2017 Global Overview" raporuna göre, 2017 yılında ise aktif sosyal medya kullanıcı sayısı 48 milyon olmuştur. 2017 yılında 62 ülkede 41,738 internet kullanıcısı ile yapılan, Universal MccanWave 9, araştırması tüm dünyada sosyal medyanın yoğunlukla kullanıldığını ortaya koymaktadir. ${ }^{46}$

Öznesi kapitalist sistem tarafından öldürülmüş modern insan, kendi öznesini canlı tutmak veya canlandırmak için bir mücadele içindedir. Ancak modern insan bu mücadeleyi kendi öznesini öldüren kapitalist sistem içinde kalarak ve yine modern hayatın kendine sağladığı imkânlarla yapmaya çalışmaktadır. Modern dönemde tek-tipleştirilmiş, yabancılaşmış, öznesi ölmüş modern insan gelişmiş multimedya imkânlarıyla oluşturduğu içerikleri teşhir etmektedir. Geleneksel dönemdeki "testinin içinde ne varsa dışarı o sızar" görüşünün yerini modern dünyada testinin içi boş bile olsa dışarı sızması istenen neyse o sızar anlayışı almıştır. Bu ise aslında hakikati olmayan bir tezahürdür; teşhirdir. Günümüzde kültürün temel üretimi görüntüdür. Hayata dair imgelerin neredeyse tamamı görüntülerle oluşturulmaktadır. Sosyal medyada teşhir edilen mutluluk tabloları hakikatsiz tezahürün açık birer örneği mahiyetindedir. Biz biliyoruz ki teşhir ettiğimiz bu görüntüleri biz oluşturduk dolayısıyla bu görüntüler hakikatsizdir. Örneğin, sosyal medyada yayınlanan bir fotoğraf ortalama üç denemenin sonunda çekilmekte ve paylaşılmaktadır. İnsanlar hayatlarında çoğu zaman kurgulanmış mutluluk zamanlarının saniyeden daha kısa süren mutluluk pozlarını paylaşmaktadırlar. Bu hakikatsiz görüntüleri paylaşan insanlar, kısa bir süre sonra sıradan hayatına dönüp hayatın sıkıntıları ile mücadele etmeye başlamaktadır. Ancak bu paylaşımları gören insanlar etraflarındaki herkesin mutlu olduğunu, kendilerinin ise mutlu olmadığını düşünmektedir. Devamında ise ya içine kapanıp karamsarlığa sürüklenmekte ya da kendisi de mutlu olmak için paylaşımlarda gördüğü mutlu insan görüntüleri gibi olmak için çalışmaktadır.

\footnotetext{
${ }^{46}$ Universal MccanWave 9 (Erişim 11 Ocak 2018).
} 


\section{DEĞERLENDIRME VE SONUÇ YERINNE}

Modern hayatın, özellikle Batı özelinde düşünüldügünde önemli getirileri olmuştur. $\mathrm{Bu}$ getirileri; insan hakları, hukukun üstünlüğü anlayışı, özgürlük, rasyonelleşme, demokrasi, sanayileşmenin sağladığı rahat yaşam biçimi vb. şeklinde saymak ve bu listeyi biraz daha uzatmak mümkündür. Batı'da bu kazanımlar aristokrasi ve Katolikliğe karşı yürütülen uzun ve mücadeleli bir dönemin sonunda elde edilmiştir ve girilen bu yeni dönemi aristokrasinin ve kilisenin mutlak egemen olduğu skolastik dönemden ayırmak ve yüceltmek için modern denmiştir. Modern dönemin başlangıcında daha çok yukarıda sayılan kazanımlar ön plana çıkmıştır. Ancak zamanla modern hayatın toplum hayatına çok sayıda olumlu etkisinin yanında, aşırı standartlaşma, sıradanlaşma, tek-tipleşme, aşırı tüketim gibi birçok olumsuz yan etkileri su yüzüne çıkmıştır. Sonuç olarak ortaya çıkan yan etkiler modern insanın öznesini öldürmüş, onu türsel özelliklerinden uzaklaştırmış ve modern insanın kendi kendisine yabancılaşmasına neden olmuştur.

Tek-tipleşmiş, sıradanlaşmış yabancılaşmış, öznesi öldürülmüş birey süreç içinde tepki olarak bir varlık mücadelesine girişmiştir. Ancak kendine yabancılaşmış ve öznesi ölmüş modern insan bu mücadeleyi kapitalizmin araçlarıyla ve modern hayatın içinde kalarak verme yoluna gitmiştir. Bu ise bu mücadeleyi gerçek bir mücadeleden ziyade bir gösteriye dönüştürmektedir. Bu mücadele şekli gerçeği değiştirmemekte aksine gerçeğin üstünü örtmektedir. Yani tesettürün bile teşhire dönüştüğü gösteri dünyasında, hakikatinden kopartılmış teşhir, hakikati gizlemek için bir tür tesettür işlevi görmektedir.

\section{KAYNAKÇA}

Adorno, W. Theodor. “Kültür Endüstrisini Yeniden Düşünmek”. Cogito 36 (Yaz 2003).

Adorno, W. Thedor \& Horkheimer, Max. Aydınlanmanın Diyalektiği. çev. Nihat Ülner \& Elif Öztarhan Karadoğan. İstanbul: Kabalcı Yayınları, 2014.

Baudrillard, Jean. Sessiz Yiğııların Gölgesinde ya da Toplumsalın Sonu. İstanbul: Ayrıntı Yayınları, 1991.

Chomsky, Noam, Medya Denetimi. İstanbul: Everest Yayınları, 2013.

Dayı, Didem. “Metafor, Bellek, Görüntü”. Görüntü Üretimi ve Gündelik Hayat. İstanbul: Kırk Yayınevi, 2013.

Debord, Guy. Gösteri Toplumu. İstanbul: Ayrıntı Yayınları, 2017.

Erdoğan, İrfan \& Alemdar, Korkmaz. Öteki Kuram, Ankara: Erk Yayınevi, 2002. 
Erkman, Fatma, Göstergebilimine Giriş. İstanbul: Alan Yayıncılık, 1987.

Giddens, Anthony. Modernliğin Sonuçları. çev. Ersin Kuşdil. İstanbul: Ayrıntı Yayınları, 2014a.

Giddens, Anthony. Modernite Birey ve Kimlik. çev. Ümit Tatlıcan. İstanbul: Say Yayınları, 2014b.

Güngör, Süleyman. Türkiye Cumhuriyeti'nin İlk Yıllarında Politikact- Aydın İlişkisi. Ankara: Nobel Yayınları, 2001.

Kellner, Douglas. Medya Gösterisi. İstanbul: Açılım Kitap, 2013.

Kellner, Douglas. Kültür Endüstrileri, Kitle iletişim Kuramları. Ankara: Ütopya Yayınevi, 2005.

Kızılçelik, Sezgin. Sosyal Bilimleri Yeniden Yapılandırmak. Ankara: Anı Yayıncılık, 2004.

Marshall, Gordon. Sosyoloji Sözlü̈̆̈̈̈. çev. Osman Akınhay \& Derya Kömürcü. Ankara: Bilim ve Sanat Yayınları, 1999.

Postman, Neil. Televizyon Öldüren Eğlence. çev. Osman Akınhay. İstanbul: Ayrıntı Yayınları, 2010.

Smith, Anthony D. Toplumsal Değişme Anlayışı. İstanbul: Gündoğan Yayınları, 2011.

Swingwood, Alan. Kitle Kültürü Efsanesi. Ankara: Bilim ve Sanat Yayınları, 1996.

Tekcan, Elvan. “Tükenen Tüketim Çağında Hakiki Gerçekliğine Öykünen San'at”. Görüntü Üretimi ve Gündelik Hayat. İstanbul: Kırk Yayınevi, 2013.

Turgul, Kurtcebe. “Görüntü Üretimi ve Gündelik Hayat Üzerine Yüzeysel Notlar". Görüntü Üretimi ve Gündelik Hayat. İstanbul: Kırk Yayınevi, 2013.

Universal MccanWave 9. Erişim 11 Ocak 2018. http://www.yugatech.com/web20/universal-mccann-social-media-research-wave-9/\#ip1CcLwe8aXk3ctw.97

Yağlı, Soner. "Gündelik Hayatımızda Akıl Tutulması: Medya Uygulamalarında Tüketim İdeolojisinin İzlerini sürmek". Gündelik Hayat ve Medya. Ankara: Babil Yayınları, 2006. 